(c) Group of authors, 2019

UDC 616.9-053.2/.3-007

DOI - https://doi.org/10.14300/mnnc.2019.14125

ISSN - 2073-8137

\title{
CONGENITAL INFECTIONS AND CONGENITAL MALFORMATION IN CHILDREN
}

\author{
Barycheva L. Yu., Golubeva M. V., Kuzmina E. S., Rakitina E. N.
}

Stavropol State Medical University, Russian Federation

ВРОЖАЕННЫЕ ИНФЕКЦИИ И ПОРОКИ РАЗВИТИЯ У АЕТЕЙ

\author{
А. Ю. Барычева, М. В. Голубева, Е. С. Кузьмина, Е. Н. Ракитина \\ Ставропольский госуАарственный МеАицинский университет, Российская ФеАерация
}

\begin{abstract}
A retrospective analysis of the results of observation of young children with intrauterine infections and congenital malformations was carried out. In 127 cases, congenital cytomegalovirus infection diagnosed in children with congenital malformations, congenital toxoplasmosis in 69. It revealed that children with developmental defects with congenital cytomegalovirus infection have higher mortality rates (61\%) than with congenital toxoplasmosis (35\%). In children with congenital cytomegaly prevails an embryopathy. In children with congenital toxoplasmosis dominate a fetopathy. Deceased children with congenital cytomegalovirus infection more often than with congenital toxoplasmosis develop defects of internal organs (congenital heart disease, anomalies of the gastrointestinal tract and urinary tract, pneumopathy). Congenital toxoplasmosis in the section dominated by fetopathies of the central nervous system and the eye.

In surviving children with congenital toxoplasmosis, severe disabling effects of central nervous system lesions and eyes in the form of occlusive hydrocephalus, cerebral palsy, complete or partial blindness, cerebro-asthenic disorders are formed more often than with cytomegalovirus infection.
\end{abstract}

Keywords: congenital cytomegalovirus infection, congenital toxoplasmosis, congenital malformations, outcomes, children

Ретроспективный анализ детей раннего возраста с пороками развития выявил у 127 из них цитомегаловирусную инфекция, у 69 - врожденный токсоплазмоз. У детей с пороками развития при врожденной цитомегаловирусной инфекции отмечены более высокие показатели летальности (61\%), чем при врожденном токсоплазмозе (35 \%). При патоморфологической оценке у детей с врожденной цитомегалией преобладают эмбриопатии, у детей с врожденным токсоплазмозом - фетопатии. У умерших детей с врожденной цитомегаловирусной инфекцией чаще, чем при врожденном токсоплазмозе, развиваются пороки внутренних органов (ВПС, пневмопатии, аномалии развития ЖКТ и МПС). При врожденном токсоплазмозе на секции преобладают фетопатии ЦНС и глаз.

У выживших детей с врожденным токсоплазмозом чаще, чем при цитомегаловирусной инфекции, формируются тяжелые инвалидизирующие последствия поражения ЦНС и глаз в виде окклюзионной гидроцефалии, ДЦП, полной или частичной слепоты, церебрастенических расстройств.

Ключевые слова: врожденная цитомегаловирусная инфекция, врожденный токсоплазмоз, пороки развития, исходы, дети

For citation: Barycheva L. Yu., Golubeva M. V., Kuzmina E. S., Rakitina E. N. CONGENITAL INFECTIONS AND CONGENITAL MALFORMATION IN CHILDREN. Medical News of North Caucasus. 2019;14(3):508-512. DOI - https://doi.org/10.14300/mnnc.2019.14125

Для цитирования: Барычева Л. Ю., Голубева М. В., Кузьмина Е. С., Ракитина Е. Н. ВРОЖДЕННЫЕ ИНФЕКЦИИ И ПОРОКИ РАЗВИТИЯ У ДЕТЕЙ. Медицинский вестник Северного Кавказа. 2019;14(3):508-512. DOI - https://doi.org/10.14300/mnnc.2019.14125

CCMV - congenital cytomegalovirus infection
CNS - central nervous system

CT - congenital toxoplasmosis
DNA - deoxyribonucleic acid

ELISA - enzyme immunoassay

PCR - polymerase chain reaction ongenital malformations of the child stably take first place among the causes of childhood disability and second place in the structure of the mortality rate of children of the first year of life, with a significant part of them being induced by intrauterine infections [1]. Infectious agents with the highest teratogenic potential include rubella virus, cytomegaly, varicella-zoster, pathogens of toxoplasmosis, mycoplasma infection [2].
Due to immunization against rubella, the leading role in the structure of viral infections forming vices belongs to congenital cytomegalovirus infection. The cytomegalovirus causes a delay in the myelination of the white matter and structural changes in the cerebral cortex [3, $4,5]$. Cortical defects in patients with congenital cytomegalovirus infection (CCMV) are characterized by the development of polymicrogyria, pahigiriya, cortical dysplasia, and heterotopy [6]. In the group of defects of the 
organogenesis period, anomalies of the gastrointestinal tract, cardiovascular, and broncho-pulmonary systems are diagnosed $[2,5,7]$.

Great importance in the structure of infectious vices of newborns has intrauterine toxoplasmosis [8]. When toxoplasma infection in the fetus often develop fetopathies of the brain and eyes. The child is born with postencephalic defects, the central nervous system, complete or partial blindness, heart defects, cleavage of the upper lip and hard palate, underdevelopment of limbs, intellectual deficiency $[9,10]$.

In this study, we evaluated the outcomes of congenital cytomegalovirus and toxoplasmic infections of congenital malformation in children.

Material and Methods. The basis of the work was a retrospective analysis of the results of observation of infants with intrauterine infections and formed malformations. In 127 cases a CCMV diagnosed in children with congenital malformations, in 69 - congenital toxoplasmosis (CT). The children were examined and monitored 1992-2012 years on the infectious disease department of the newborns, neurological department of the Regional Children's Clinical Hospital, two children's department of the Regional Clinical Hospital «Regional Clinical Infectious Diseases Hospital», infectious and resuscitation departments Central Central of the Stavropol Territory.

A set of serological and molecular biological methods was used to diagnose CCMV and CT with the determination of specific IgM and IgG with the avidity index to CMV by the ELISA method in mothers and children in paired sera. PCR performed the detection of CMV DNA and Toxoplasmosis in the blood.

Detection of IgG to CMV with dynamic observation during the year was noted in $74 \%$ of children, IgM CMV in $7 \%$, CMV DNA in the blood - in $48 \%$ of children. In $23 \%$ of cases, the diagnosis of CCMV was verified only after death according to the pathomorphological study.

Detection of IgG for Toxoplasma Gondi was observed in $59 \%$ of children during the year, IgM Toxo in $11 \%$, Toxoplasma Gondi in the blood in $27 \%$ of children. In 19 out of 27 deceased children with $\mathrm{CT}$, the diagnosis was verified after death according to the pathomorphological study. The analysis of the protocols of autopsies of dead children was carried out in work based on the design of Regional Children's Clinical Hospital, and the Department of Pathological Anatomy of Stavropol State Medical University 113 cases of sectional observations had a pathomorphological picture of CCMV, 40 - CT.

For the statistical analysis of data is using a package of programs «AtteStat 10.5.1» (Russian Federation). In assessing the differences in qualitative characteristics, the criterion 2 was used.

Results and Discussion. The cerebral form of CCMV was diagnosed in 24 children, and they characterized by the development of cytomegalovirus encephalitis or meningoencephalitis.

In the generalized form (103 children), the disease was born with severe CNS depression (68\%), toxicity (40\%), jaundice (32\%), hemorrhagic syndrome (14\%) and was accompanied by development ( $49 \%)$, encephalitis or meningoencephalitis (32\%), hepatitis (26\%), carditis $(20 \%)$, enterocolitis (17\%), nephritis (13\%).

In $61 \%(78)$ cases, the state of children with CCMV progressively worsened to a lethal outcome with the development of respiratory and cardiovascular insufficiency $(51 \%)$, edema-swelling of the brain (38\%), disseminated intravascular coagulation syndrome (33\%), multi-organ failure (13\%), toxicodystrophic condition (7\%).

Congenital toxoplasmosis in 69 children with congenital malformations in the form of generalized (21 children), meningoencephalic (12), and encephalic (36) forms were diagnosed.

The severity of the condition in generalized form was due to intoxication or toxicosis $(91 \%)$, the formation of polyorganous lesions with the development of pneumonia (86\%), meningoencephalitis (38 \%), carditis (33\%), hepatitis (43\%), nephritis (24\%), enterocolitis (57\%).

CNS lesion in meningoencephalic form of VT (12 children) was acute (5) or subacute (7). Three children had «latent» meningoencephalitis, realized by the second half of the year, signs of intracranial hypertension, lagging behind the psychomotor and speech development, seizures, the formation of occlusive hydrocephalus.

In 36 children with an encephalic form of CT and congenital hydrocephalus was diagnosed. In all cases, occlusive internal hydrocephalus was recorded. In $33 \%$ of children, it was decompensated, which required surgical intervention. In the remaining cases (67\%), hydrocephalus had a compensated form with signs of progression of the process. In $22 \%$ of children from birth, hydrocephalus was combined with microcephaly. Specific eye damage in children with encephalic form was observed in $89 \%$ of children, including developmental defects in $50 \%$.

Ophthalmic examination diagnosed total or partial atrophy of optic nerves (42\%), chorioretinitis (22\%), microphthalmia (19\%), cataract of one or both eyes (19\%), iris and retina coloboma ( $8 \%)$, uveitis $(6 \%)$, keratitis (6\%), anophthalmia (6\%).

Mortality in children with malformations at CT was significantly lower than with CCMV and amounted to $35 \%$, $\mathrm{p}<0.05$

In the pathomorphological examination, in children with CT prevailed fetopathy (90\%), in children with CCMV - embryopathy (55\%), $\mathrm{p}<0.05$.

Congenital heart defects in the overall structure of congenital malformations were more often diagnosed with CCMV than with CT and were $13 \%$ and $4 \%$ during life, $45 \%$ and $25 \%$ in the section, respectively. However, significant differences were recorded only from the autopsy material (Table 1).

In deceased children with CT, fibroelastosis (13\%), interventricular septum ( $5 \%$ ), defects of interatrial (3\%), and dextracardia (3\%) were verified. Children with CCMV had defects in interatrial septum $(7 \%)$, interventricular septum (2\%), stenosis of the aortic orifice ( $1 \%)$, fusion of mitral valve flaps ( $1 \%)$, open arterial duct $(1 \%)$, crestlike deformation of the endocardium (1\%). Relatively more often than in VT, endocardial fibroelastosis was determined $(33 \%, \mathrm{p}<0.05)$.

Congenital anomalies of the bronchopulmonary system were not diagnosed during life. Pathomorphological analysis of pneumopathy was more often detected with CCMV (35\% and $13 \%, p<0.05)$. In the structure of defects in $\mathrm{CT}$, congenital atelectasis ( $8 \%$ ), congenital lung cysts ( $3 \%)$, bronchiectasis ( $3 \%)$, bullous emphysema (3\%), were detected. With CCMV, atelectasis (8\%), hypoplasia of the lung fraction ( $1 \%)$, and congenital bronchiectasis (1\%) were diagnosed. More often than in the CT group, underdevelopment of lung tissue was defined (12\%, p<0.05) (Table 1).

Gaps in the development of the gastrointestinal tract were more often formed in VCMV. In life, their prevalence in the CCMV group was $11 \%$, in the CT group - $5.8 \%$, after death $23 \%$ and $8 \%, p<0.05$, respectively (Table 1 ).

The prevalence of anomalies of the urinary system during life in children with CCMV and CT did not differ significantly. In deceased children with CCMV, the defects of the Genitourinary system were diagnosed more often $(30 \%, p<0.05)$. 
Malformations in children with congenital cytomegalovirus and toxoplasmic infections

Table 1

\begin{tabular}{|c|c|c|c|c|}
\hline \multirow[b]{2}{*}{ Malformations } & \multicolumn{2}{|c|}{ CCMV } & \multicolumn{2}{|c|}{$\mathrm{CT}$} \\
\hline & $\begin{array}{c}\text { During lifetime } \\
(n=127)\end{array}$ & $\begin{array}{l}\text { Into sections } \\
(n=113)\end{array}$ & $\begin{array}{l}\text { During lifetime } \\
(n=69)\end{array}$ & $\begin{array}{l}\text { Into sections } \\
(n=40)\end{array}$ \\
\hline CNS malformations & $52 \%$ & $39 \%$ & $78 \% *$ & $63 \% *$ \\
\hline Noncommunicating hydrocephaly & $19 \%$ & $17 \%$ & $70 \% *$ & $50 \% *$ \\
\hline Mixed hydrocephalus & $21 \%$ & $20 \%$ & $3 \%$ & $10 \%$ \\
\hline Microcephaly & $13 \%$ & - & $7 \%$ & $10 \%$ \\
\hline Pachygyria & - & $2 \%$ & - & $2,5 \%$ \\
\hline Agenesis of the corpus callosum & - & $1 \%$ & - & - \\
\hline Malformations of the eye & $17 \%$ & $8 \%$ & $49 \% *$ & $23 \% *$ \\
\hline Anophthalmos & - & - & $3 \%$ & $3 \%$ \\
\hline Microphthalmia & - & - & $10 \% *$ & $8 \% *$ \\
\hline Coloboma & $2 \%$ & $2 \%$ & $4 \%$ & - \\
\hline Congenital cataracts & $1 \%$ & $3 \%$ & $10 \%$ & - \\
\hline Atrophy of the optic disc & $14 \%$ & $4 \%$ & $23 \%$ & $13 \%$ \\
\hline Congenital Heart Disease & $13 \%$ & $45 \% *$ & $4 \%$ & $25 \%$ \\
\hline Defect of interatrial septum & $7 \%$ & $4 \%$ & $1 \%$ & $3 \%$ \\
\hline Defect of interventricular septum & $2 \%$ & $4 \%$ & $1 \%$ & $5 \%$ \\
\hline Dekstrakardiya & - & - & - & $3 \%$ \\
\hline Aortic stenosis & - & $1 \%$ & - & - \\
\hline Fusion of the leaflets of the mitral valve & - & $1 \%$ & - & - \\
\hline Patent ductus arteriosus & $1 \%$ & $1 \%$ & - & - \\
\hline $\begin{array}{l}\text { Comb-shaped deformation } \\
\text { of the endocardial }\end{array}$ & - & $1 \%$ & - & - \\
\hline Fibroelastosis & $4 \%$ & $33 \% *$ & $1 \%$ & $13 \%$ \\
\hline Pneumopathy & - & $35 \% *$ & - & $13 \%$ \\
\hline Congenital lung cysts & - & - & - & $3 \%$ \\
\hline Congenital bronchiectasis & - & $1 \%$ & - & $3 \%$ \\
\hline Congenital bullous emphysema & - & - & - & $3 \%$ \\
\hline Anectasis & - & $12 \%$ & - & $8 \%$ \\
\hline Hypoplasia of the lung tissue & - & $12 \% *$ & - & - \\
\hline Bronchi hypoplasia & - & $8 \%$ & - & - \\
\hline Lobe hypoplasia & - & $1 \%$ & - & - \\
\hline $\begin{array}{l}\text { Congenital defects } \\
\text { of the gastrointestinal tract }\end{array}$ & $11 \%$ & $23 \% *$ & $6 \%$ & $8 \%$ \\
\hline Esophageal atresia & $5 \%$ & $4 \%$ & $1 \%$ & - \\
\hline Anorectal atresia & $4 \%$ & $4 \%$ & $1 \%$ & $3 \%$ \\
\hline Atresia of the jejunum and ileum & - & $4 \%$ & - & - \\
\hline Doubling the intestinal tube & - & $3 \%$ & - & - \\
\hline Gastroschisis & $2 \%$ & $3 \%$ & $1 \%$ & - \\
\hline Overall bowel mesentery & - & $5 \%$ & - & $3 \%$ \\
\hline Aganglioz colon & - & $6 \%$ & - & $3 \%$ \\
\hline Narrowing of the bile duct & - & $1 \%$ & - & $3 \%$ \\
\hline Genitourinary system anomalies & $7 \%$ & $29 \% *$ & $4 \%$ & $10 \%$ \\
\hline Kidney Doubling & $1 \%$ & $2 \%$ & $1 \%$ & $3 \%$ \\
\hline Absence of kidney & $1 \%$ & & & \\
\hline Hypospadias & $3 \%$ & $2 \%$ & $1 \%$ & $3 \%$ \\
\hline Cryptorchism & - & - & $1 \%$ & - \\
\hline Hypogonadism & $3 \%$ & $4 \%$ & $1 \%$ & - \\
\hline Cystic renal dysplasia & - & $4 \%$ & - & $5 \%$ \\
\hline Hypoplasia of nephrons & - & $19 \% *$ & & \\
\hline Osteochondral defects & $8 \%$ & $12 \%$ & $7 \%$ & $8 \%$ \\
\hline Platispondiliya & $1 \%$ & $1 \%$ & $1 \%$ & $3 \%$ \\
\hline Polydactyly & $3 \%$ & $6 \%$ & $1 \%$ & $3 \%$ \\
\hline Aplasia of the metacarpals & $1 \%$ & $1 \%$ & $1 \%$ & - \\
\hline Aplasia of the phalanges & $1 \%$ & $1 \%$ & $1 \%$ & - \\
\hline Abnormal growth of the fingers & $1 \%$ & $1 \%$ & $1 \%$ & - \\
\hline Deformation of the sacrum and coccyx & - & - & - & $3 \%$ \\
\hline Hip dysplasia & - & $1 \%$ & $3 \%$ & - \\
\hline Bilateral clubfoot & $1 \%$ & - & $1 \%$ & - \\
\hline Micrognathia & $1 \%$ & $1 \%$ & - & - \\
\hline
\end{tabular}

\footnotetext{
${ }^{*} p<0.05$, the reliability of differences in children with CCMV and CT (criterion $\chi 2$ ).
} 
Anomalies of bone-cartilaginous tissue during life were recorded in $8 \%$ of children with CCMV and $7 \%$ of children with CT, with a pathomorphological examination in $12 \%$ and $8 \%$.

The developmental defects of the central nervous system in the structure of congenital malformations in infected children predominated in congenital toxoplasmosis, $p<0.05$. Occlusion internal hydrocephalus during life was more often recorded in children with CT $(70 \%)$ than with CCMV (51\%). Mixed hydrocephalus and microcephaly were more often verified with CCMV. However, no significant differences were revealed. In deceased children, occlusal internal hydrocephalus was more frequently encountered with CT - $50 \%$, less usually with CCMV - $17 \%$, $p<0.05$. Mixed hydrocephalus was recorded in $3 \%$ and $21 \%$, respectively.

The developmental defects of the eyes were more often observed with congenital toxoplasmosis. In the structure of the anomalies diagnosed during life, the defects of the organ of vision were $49 \%$ and were represented by atrophy of the optic nerve (23\%), congenital cataracts (10\%), microphthalmia (10\%), coloboma (4\%), anophthalmia (3\%). Among the developmental abnormalities in CCMV, the developmental defects were observed in $17 \%$ of cases in the form of atrophy of optic discs (14\%), colobomas (2\%), congenital cataracts (1\%).

In the pathomorphological study, the developmental defects in CT were diagnosed in $49 \%$, with CCMV - in $23 \%, p<0.05$. With toxoplasma infection, microphthalmia was more often verified $-10 \%, p<0.05$.

In surviving children with malformations against the background of congenital cytomegalovirus and toxoplasmic infections, the disabling effects of CNS involvement predominated (Table 2).

Occlusal internal hydrocephalus often developed with congenital toxoplasmosis, mixed hydrocephalus with CCMV, $\mathrm{p}<0,05$. Microcephaly was more frequently detected in the outcome of the CCMV. However, there were no significant differences with the CT group. Children's cerebral palsy formed in $53 \%$ of children with CT. In children with CCMV, it showed up $27 \%, p<0.05$.

Anomalies in the development of the eye were more often detected in children with congenital toxoplasmosis

(69\%, p<0.05), including those with complete or partial blindness $(33 \%, p<0.05)$. Cerebrasthenic behavior disorders predominated in children with CT - $62 \%$, $\mathrm{p}<0.05$.

Conclusions. Children with developmental defects with congenital cytomegalovirus infection have higher mortality rates $(61 \%)$ than with congenital toxoplasmosis (35\%). When pathomorphological analysis with congenital CMV, embryopathy prevails, in children with congenital toxoplasmosis - fetopathy.

Deceased children with CCMV more often than in case of congenital toxoplasmic infection, defects in the development of internal organs, including a congenital heart defect, pneumopathy, anomalies in the development of the gastrointestinal tract and genitourinary tract, are verified. Congenital toxoplasmosis in the section is dominated by fetopathies of the central nervous system and the eye.

In surviving children with congenital toxoplasmosis, severe disabling effects of CNS lesions and eyes in the form of occlusive hydrocephalus, cerebral palsy, complete or partial blindness, cerebrosthenic disorders formed more often than with CCMV.

Disclosures:

The authors declare no conflict of interest.

\section{References}

1. Vermillion M. S., Klein S. L. Pregnancy and infection: using disease pathogenesis to inform vaccine strategy. NPJ Vaccines. 2018;3:6.

https://doi.org/10.1038/s41541-017-0042-4

2. Golubeva M. V., Barycheva L. Yu., Oguzova E. Yu. The role of congenital cytomegalovirus infection in disorders of immune adaptation mechanisms. Medical News of North Caucasus. 2008;3(11):15-19.

3. Britt W. J. Controversies in the natural history of congenital human cytomegalovirus infection: the paradox of infection and disease in offspring of women with immunity prior to pregnancy. Medical Microbiology and Immunology. 2015;204(3):263-271. https://doi.org/10.1007/s00430-015-0399-9

4. Schleiss M. R. Congenital cytomegalovirus: Impact on child health. Contemp Pediatr. 2018;35(7):16-24

5. Krakar G., Đaković I., Delin S., Bošnjak V. M. Evolutive leukoencephalopathy in congenital cytomegalovirus infection. J. Child. Neurol. 2015;30(1):93-95 https://doi.org/10.1177/0883073813514292
6. Pascual-Castroviejo I., Pascual-Pascual S. I., Velazquez-Fragua R., Viaño Lopez J. Congenital cytomegalovirus infection and cortical/subcortical malformations. Neurologia. 2012;27(6):336-342. https://doi.org/10.1016/j.nrl.2011.12.017

7. Razin M. P., Minaev S. V., Axelrov M. A., Tarakanov V. A., Svirsky A. A. [et al.] Diagnosis and treatment of the congenital diaphragmatic hernia in children: a multicenter research Medical News of North Caucasus. 2019;14(2):302-308. https://doi.org/10.14300/mnnc.2019.14073

8. Wallon M., Peyron F. Congenital Toxoplasmosis: A Plea for a Neglected Disease. Pathogens. 2018;7(1):25. https://doi.org/10.3390/pathogens 7010025

9. Tedford E., McConkey G. Neurophysiological Changes Induced by Chronic Toxoplasma gondii Infection. Pathogens. 2017:6(2):19. https://doi.org/10.3390/pathogens6020019

10. Schlüter D., Barragan A. Advances and Challenges in Understanding Cerebral Toxoplasmosis. Front. Immunol. 2019:10:242. https://doi.org/10.3389/fimmu.2019.00242 
About authors:

Barycheva Lyudmila Yurievna, DMSc, Professor, Head of the Department of immunology; tel.: +79187405484; e-mail: for_ludmila@inbox.ru

Golubeva Marina Viktorovna, MD, DMSc, Professor, Head of the Department of childhood infectious diseases;

tel.: 79187468795; e-mail: mmvg@rambler.ru

Kuzmina Ekaterina Sergeevna, MD, Assistant of the Department of immunology; tel.: +79620104810; e-mail: katerinamedic@mail.ru

Rakitina Elena Nikolaevna, postgraduate student; tel.: +79624507653; e-mail: rakitina_1989@bk.ru

(c) Group of authors, 2019

UDC 616.735.5.002.61:34.49.003

DOI - https://doi.org/10.14300/mnnc.2019.14126

ISSN - 2073-8137

\title{
LEUKOCYTIC RESPONSES IN PERIPHERAL BLOOD AND PECULIARITIES OF BONE MARROW HEMATOPOIESIS IN ACUTE AND CHRONIC INFLAMMATION ON A BACKGROUND OF LOCAL REMOVAL OF NON-PHAGOCYTIC GRANULOCYTES
}

Sirak A. G. ' , Piskareva E. I. ', Magomedova O. G. ${ }^{1}$, Arutjunova A. P. ${ }^{1}$, Dolgashova M. A. ' , Didenko M. O. ', Andriutsa N. S. ${ }^{2}$, Kochkarova Z. M. ${ }^{1}$

${ }^{1}$ Stavropol State Medical University, Russian Federation

2 I. M. Sechenov First Moscow State Medical University (Sechenov University),

Russian Federation

\section{АЕЙКОЦИТАРНАЯ РЕАКЦИЯ ПЕРИФЕРИЧЕСКОЙ КРОВИ И ОСОБЕННОСТИ КОСТНОМОЗГОВОГО КРОВЕТВОРЕНИЯ ПРИ ОСТРОМ И ХРОНИЧЕСКОМ ВОСПААЕНИИ НА ФОНЕ АОКААЬНОГО УАААЕНИЯ НЕФАГОЦИТИРУЮЩИХ ГРАНУАОЦИТОВ}

\author{
А. Г. Сирак ${ }^{1}$, Е. И. Пискарева ${ }^{1}$, О. Г. Магоменова ${ }^{1}$, А. П. Арутюнова ${ }^{1}$, \\ М. А. Аолгашова ', М. О. Аиленко ', Н. С. Анариуца ${ }^{2}$, 3. М. Кочкарова ${ }^{1}$ \\ ${ }^{1}$ Ставропольский госуАарственный МеАицинский университет, Российская ФеАерация \\ 2 Первый Московский госуАарственный меАицинский университет \\ им. И. М. Сеченова (Сеченовский Университет), Российская ФеАерация
}

\footnotetext{
The aim of the present study was to investigate leukocytic responses in peripheral blood and the features of bone marrow hematopoiesis in acute and chronic inflammatory processes against a background of experimental localized removal of non-phagocytic granulocytes. Bone marrow hematopoiesis was assessed by calculating the total number of myelokaryocytes and the cellular composition of bone marrow obtained from the femurs of 24 male Wistar rats weighing 180-220 g. During the inflammatory process after prior localized removal of non-phagocytic granulocytes, hematopoiesis-especially lymphopoiesis-was enhanced, and there was a decrease in leukocyte counts from the bone marrow into the blood.
}

Keywords: acute inflammation, chronic inflammation, non-phagocytic granulocytes, experiment

Проведено изучение особенностей костномозгового кроветворения и лейкоцитарной реакции периферической крови при остром и хроническом воспалительном процессе на фоне локального удаления нефагоцитирующих гранулоцитов. Костномозговое кроветворение изучали путем подсчета общего количества миелокариоцитов и клеточного состава костного мозга, полученного из бедренной кости 24 крыс-самцов линии Wistar массой 180-220 г. Установлено, что при воспалительном процессе на фоне предварительного удаления НГ из очага происходит усиление гемопоэза, особенно лимфопоэза, и уменьшение поступления лейкоцитов из костного мозга в кровь.

Ключевые слова: острое воспаление, хроническое воспаление, нефагоцитирующие гранулоциты, эксперимент

For citation: Sirak A. G., Piskareva E. I., Magomedova O. G., Arutjunova A. P., Dolgashova M. A., Didenko M. O., Andriutsa N. S., Kochkarova Z. M. LEUKOCYTIC RESPONSES IN PERIPHERAL BLOOD AND PECULIARITIES OF BONE MARROW HEMATOPOIESIS IN ACUTE AND CHRONIC INFLAMMATION ON A BACKGROUND OF LOCAL REMOVAL OF NON-PHAGOCYTIC GRANULOCYTES. Medical News of North Caucasus. 2019;14(3):512-516.

DOI - https://doi.org/10.14300/mnnc.2019.14126 